http://e-journal.stit-islamic-village.ac.id/index.php/JECIES

\title{
PENDIDIKAN KARAKTER ANAK USIA DINI DALAM KEGIATAN BERMAIN SENTRA
}

\author{
Rosita, Neneng Alawiyah, Amita Diananda \\ Program Studi Pendidikan Anak Usia Dini STIT Islamic Village Tangerang \\ Email: \\ rosita.stit@gmail.com, nenengalawiyah.stit@gmail.com, \\ amitadiananda.stit@gmail.com
}

Received: 03 Maret, 2021.

Accepted: 23 Maret, 2021.

Published: 31 Maret, 2021

\begin{abstract}
This qualitative research was conducted with a background to enrich the discourse and paradigm regarding the pattern of Early Childhood education in character formation. In addition, researchers want to detect and see the effects of center learning on the formation of early childhood character. Although each learning pattern has an influence and has a change in students, the center's activities have a unique value in character planting. This study uses a descriptive qualitative approach using Spradley analysis. The results of the study describe the state of character education in learning centers in the Islamic Village kindergarten. That the internalization of character values is carried out through the foothold in the center from the initial conditioning to the footing after playing. Thus this research is expected to provide a positive new discourse and has the aim to provide a true understanding of what is happening around us.
\end{abstract}

Keywords: Education, Character, Early Childhood, Playing

\begin{abstract}
ABSTRAK
Penelitian kualitatif ini dilakukan dengan latar belakang memperkaya wacana dan paradigma mengenai pola pendidikan Anak Usia Dini dalam pembentukan karakter. Selain itu peneliti ingin mendeteksi dan melihat efek pembelajaran sentra terhadap pembentukan karakter anak usia dini. Meskipun setiap pola pembelajaran memiliki pengarub dan memiliki perubahan terbadap peserta didiknya, namun kegiatan sentra memiliki nilai keunikan dalam penanaman karakter. Penelitian ini menggunakan pendekatan kualitatif deskrptif dengan menggunakan analisis Spradley. Hasil penelitian menggambarkan keadaan pendidikan karakter dalam pembelajaran sentra di TK Islamic Village. Internalisasi nilai-nilai karakter dilaksanakan melalui pijakanpijakan di sentra dari sejak pengkondisian awal sampai pijakan setelah main.Dengan demikian penelitian ini diharapkan dapat memberikan wacana baru yang positif dan memiliki tujuan untuk. memberikan pemahaman sebenarnya yang terjadi di sekitar kita.
\end{abstract}

Kata Kunci: Pendidikan, Karakter, Anak Usia Dini, Bermain 


\section{PENDAHULUAN}

Anak Usia dini merupakan fase emas yang menyerap setiap informasi di sekitarnya. Sehingga perilaku yang bernilai atau pun sampah akan terpola dalam memori panjang yang ada di otaknya. Proses dalam mendidik anak usia dini pada saat ini menjadi perbincangan yang hangat. Teori-teorinya pun dikaji demi meningkatkan perkembangan yang maksimal bagi anak usia dini. Hal ini dilakukan untuk menyambut demography Indonesia di tahun 2045, dengan harapan anak usia dini beberapa tahun ini menjadi pemimpin masa depan yang mumpuni, tidak hanya mapan secara intelektual tapi juga secara emosi dan berkarakter.

Dalam Undang-undang No 20 Tahun 2003 tentang sistem Pendidikan Nasional mengamanatkan dengan tegas perlunya penanganan pendidikan anak usia dini. Hal ini searah dengan tujuan dari Pasal 1 butir 14 bahwa "Pendidikan anak usia dini adalah suatu usaha pembinaan yang ditujukan kepada anak sejak lahir sampai usia enam tahun, yang dilakukan melalui pemberian rangsangan atau stimulasi pendidikan untuk membantu pertumbuhan dan perkembangan jasmani dan rohani agar anak memiliki kesiapan dalam memasuki pendidikan selanjutnya". Hal ini sesuai dengan pendapat para ahli yang menyatakan bahwa masa usia dini adalah masa keemasan (golden age) yang harus mendapatkan perhatian khusus, mengingat usia ini merupakan periode kritis dalam perkembangan manusia, periode yang sangat menentukan bagi pertumbuhan dan perkembangan anak. Tahun-tahun awal dalam usia anak merupakan masa perkembangan yang intens: periode ketika anak-anak memperoleh pengetahuan tentang diri dan lingkungan mereka, mengembangkan kemampuan dasar pengetahuan dan memperoleh citra diri dan keamanan yang berlangsung seumur hidup. Pada masa ini anak dengan mudah menyerap semua informasi melalui pengamatan dari semua inderanya: penglihatan, pendengaran, penciuman, pengecapan dan sentuhan. Pengamatan, peniruan dan eksperimen, anak-anak mempelajari dunia sekitar dengan bahasa mereka yaitu bermain.

Bermain merupakan cara yang tepat untuk mengembangkan kemampuan anak baik fisik, kognitif, sosial emosional, bahasa dan seni. Melalui bermain anak dapat mengeksplor dirinya, melalui bermain anak menyerap pesan dari permainan dan mainan sepanjang tahap pertumbuhannya. Bermain adalah fenomena alami, sebelum memberikan mainan yang akan digunakan, maka orang dewasa yang menjadi fasilitator perlu memahami prinsip bermain yaitu memperkaya kedua sisi otak (belahan otak kanan dan kiri).

Banyak penelitian menegaskan aspek penting perkembangan mental, sosial, dan syaraf sejak dini. Para peneliti menemukan bahwa anak-anak yang tidak bermain dan jarang disentuh, otaknya 20-30\% lebih kecil dari otak anak 
normal seusia mereka. Dan mainan menstimulasi sinapsis pada setiap neuron atau sel otak 25\% lebih banyak. (Auerbacch, 2007)

Kegiatan yang menyenangkan dengan bermain, sentuhan hangat dari orang tuanya dan contoh yang baik akan membentuk daya tahan anak usia dini dalam mengarungi kehidupan selanjutnya. Dan ini menjadi karakter yang kuat pada anak dan menjadi identitas yang melekat sampai mereka dewasa. Dengan demikian anak usia dini memiliki perkembangan yang sangat dinamis, baik secara intelektual ataupun emosional dan berkarakter apabila distimulasi dengan baik. Dan ini sesuai dengan harapan pemerintah Republik Indonesia untuk memberikan penguatan pendidikan karakter dalam peraturan presiden (Perpres) Nomor 87 Tahun 2017 tentang Penguatan Pendidikan Karakter. Perpres ini hadir dengan pertimbangan bahwa dalam rangka mewujudkan bangsa yang berbudaya melalui penguatan nilai-nilai religius, jujur, toleran, disiplin, bekerja keras, kreatif, mandiri, demokratis, rasa ingin tahu, semangat kebangsaan, cinta tanah air, menghargai prestasi, komunikatif, cinta damai, gemar membaca, peduli lingkungan, peduli sosial, dan bertanggung jawab akan mampu memupuk karakter yang mumpuni di tahun 2045 nanti melalui kegiatan bermain yang bermutu seperti metode sentra. Hal inilah yang menggugah pemikiran peneliti untuk menelaah pemebelajaran karakter dengan metode sentra.

\section{Pendidikan Anak Usia dini}

Pendidikan merupakan suatu upaya untuk memanusiakan manusia. Seperti yang diungkapkan Aristoteles bahwa pendidikan merupakan proses mencapai kesempurnaan manusia (Yudhistira, 2012). Artinya melalui proses pendidikan diharapkan melahirkan manusia-manusia yang baik.

Menurut John Dewey Pendidikan adalah usaha untuk mengasah kemampuan secara intelektual dan emosional ke arah alam dan sesama manusia. Sedangakan menurut Jean J. Rousseau, Pendidikan adalah memberi kita perbekalan yang tidak ada pada masa kanak-kanak, akan tetapi kita membutuhkannya pada waktu dewasa. Sedangkan menurut Rasulullah Muhammad SAW dalam haditsnya, Pendidikan merupakan proses seumur hidup atau pendidikan sepanjang masa (long life education) karena belajar adalah proses dari saat masih dalam bauaian sampai liang lahat. Dengan demikian pendidikan merupakan proses "menjadi" bagi setiap individu berdasarkan kegiatan yang dilakukan serta pengaruh yang diterima dari lingkungan sekitarnya. Oleh sebab itu stimulasi dan pengaruh yang diberikan sejak dini usia penting untuk bekal dan masa depan seseorang untuk mengarungi kehidupannya di masa yang akan datang. Anak Usia dini merupakan warisan masa depan dan calon penerus kehidupan selanjutnya. 
Oleh karena itu memberikan stimulasi dan pola treatment yang tepat memberikan dampak yang tepat pula untuk anak di masa yang akan datang.

Pengertian anak usia dini secara umum adalah anak-anak di bawah usia 6 tahun. Pemerintah melalui UU Sisdiknas mendefinisikan anak usia dini adalah anak dengan rentang usia 0-6 tahun. Batasan yang dipergunakan oleh the National Association For The Eduction Of Young Children (NAEYC) atau salah satu lembaga PBB, dan para ahli pada umumnya mengungkapkan bahwa anak usia dini atau "early childhood" adalah anak yang sejak lahir sampai dengan usia delapan tahun (0-8 Tahun).

Dengan demikian, pendidikan Anak Usia Dini adalah jenjang pendidikan sebelum pendidikan dasar, yang merupakan suatu upaya pembinaan yang ditujukan bagi anak sejak lahir sampai dengan usia enam tahun. Pendidikan ini dilakukan melalui pemberian rangsangan pendidikan untuk membantu pertumbuhan memasuki pendidikan lebih lanjut, yang diselenggarakan pada jalur formal, nonformal, dan informal di Indonesia.

Hal ini berdasarkan Undang-Undang Sisdiknas No. 20 Tahun 2003 menjelaskan bahwa Pendidikan anak usia dini adalah suatu usaha pembinaan yang ditujukan kepada anak sejak lahir sampai usia enam tahun, yang dilakukan melalui pemberian rangsangan atau stimulasi pendidikan untuk membantu pertumbuhan dan perkembangan jasmani dan rohani agar anak memiliki kesiapan dalam memasuki pendidik selanjutnya

Memberikan stimulasi yang tepat untuk anak usia dini merupakan tugas yang tidak mudah, membutuhkan pengetahuan bagi setiap pendidik baik orang tua, guru atau pun masyarakat yang terlibat agar seorang anak menjadi manusia-manusia unggul. Karena setiap anak unik. Jean J. Rousseau dalam Crain mengungkapkan bahwa (Crain, 2007):

1. Anak tumbuh, berkembang, belajar dan mehamami sesuatu dengan cara mereka sendiri sesuai rencana alam. Alam seperti guru yang tersembunyi yang mendorong anak mengembangkan kemampuan yang berbeda-beda. Jika anak ingin dibantu dalam proses ini, maka setiap orang harus mempelajari semua hal tentang tahapan perkembangan manusia.

2. Dalam setiap tahapan anak memiliki karakteristik yang unik.

3. Pendidikan berpusat pada anak, "Ajarlah murid-muridmu sesuai usianya.

Dengan kata lain pendidikan anak usia dini merupakan proses yang dilakukan berdasarkan perkembangan usia, memberikan sarana yang maksimal dan menjadi fasilitator yang mengerti tahapan perkembangan anak, karena pertumbuhan sel syaraf otak,fisik dan non fisik anak masih belum optimal. Hal ini pun tidak terlepas dari gaya belajar anak atau setiap individu.

Gaya belajar adalah cara belajar yang terdiri dari berbagai kombinasi untuk menyerap, lalu mengatur, dan mengolah informasi (Deporter,Mike,Bobby \& Hernacki, 2000). Menyerap informasi membutuhkan 
modalitas yaitu cara termudah untuk menyerapnya, kemudian dominasi otak yaitu cara mengatur dan mengolah informasi. Dan gaya belajar anak usia dini terdiri dari beberapa kriteria, yaitu visual, auditory dan kinesthetik.

1. Visual merupakan cara belajar dengan cara melihat atau menggunakan matanya, sehingga anak yang memiliki tipe pembelajar visual akan lebih mudah menyerap informasi dengan melihat instruksi ataupun informasi dihadapannya.

2. Auditorial : belajar dengan cara mendengar, tipe ini merupakan proses menyerap informasi yang tanpa dilihat anak tapi instruksi dan informasinya tersampaikan.

3. Kinestetik : belajar dengan cara bergerak,bekerja, dan menyentuh, dalam tipe ini anak akan lebih mudah meyerap informasi apabila kegiatan pembelajaran dilakukan dengan instruksi langsung dalam sebuah gerakan (praktek langsung).

Dengan kata lain gaya belajar merupakan kegiatan atau cara menyerap informasi melalui seluruh panca inderanya. Dan kegiatan yang melibatkan seluruh panca indera merupakan tekhnik yang brilian bagi anak usia dini untuk menyerap informasi.

\section{Pendidikan Karakter untuk Anak Usia Dini}

Karakter dalam Amrullah Syahrbini diberi arti a distinctive differinting mark (tanda atau sifat yang membedakan seseorang dengan orang lain) (Syarbini, 2014). Sedangkan secara terminologis, kata karakter menurut Endang Sumantri adalah suatu kualitas positif yang dimiliki seseorang, sehingga membuatnya menarik dan atraktif; seseorang yang unusual atau memiliki kepribadian ekssentrik. Menurut Doni Koesuma karakter sama dengan kepribadian.

Dengan demikian karakter merupakan sifat yang stabil, dan khusus yang melekat dalam diri seseorang hingga membuatnya bersikap dan bertindak secara otomatis, tidak dapat dipengaruhi oleh keadaan, dan tanpa memerlukan pemikiran atau pertimbangan terlebih dahulu. Pengertian karakter memiliki kesamaaan dengan definisi akhlak dalam Islam yaitu, perbuatan yang telah menyatu dalam jiwa atau diri seseorang atau spontanitas dalam bersikap sehingga ketika muncul tidak perlu dipikirkan lagi.

Sedangkan pendidikan karakter menurut Thomas Lichona dalam Amrullah Syahrbini adalah upaya membentuk atau mengukir kepribadian manusia melalui proses knowing the good (mengetahui kebaikan), loving the good (mencintai kebaikan), acting the good (melakukan kebaikan), yaitu proses pendidikan yang melibatkan tiga ranah: pengetahuan moral (moral knowing), perasaan moral (moral feeling atau moral loving), dan tindakan moral (moral acting/moral doing), sehingga perbuatan mulia bisa terpatri dalam jiwa 
seseorang dan menjadi habit of mind, heart, and hands. Namun tanpa melibatkan ketiga ranah tersebut pendidikan karakter tidak akan berjalan efektif (Syarbini, 2014).

Sehingga dapat dikatakan bahwa pendidikan karakter merupakan sebuah proses untuk menumbuhkan, mengembangkan, mendewasakan, menata, mengarahkan agar potensi yang ada pada diri anak bisa muncul serta berkepribadian baik yang nantinya dapat bermanfaat bagi dirinya dan juga lingkungannya.

Jika mengacu pada pedoman pendidikan karakter yang di keluarkan oleh Kemendiknas, pembelajaran karakter di lembaga formal (sekolah), setidaknya memuat 18 (delapan belas) nilai karakter, yaitu : (1) religius, (2) jujur, (3) toleransi, (4) disiplin, (5) kerja keras, (6) kreatif, (7) mandiri, (8) demokratis, (9) rasa ingin tahu, (10) semangat kebangsaan, (11) cinta tanah air, (12) menghargai prestasi, (13) bersahabat/ komunikatif, (14) cinta damai, (15) gemar membaca, (16) peduli lingkungan, (17) peduli sosial, dan (18) tanggung jawab.

Pendidikan karakter yang ditanamkan pada anak akan membentuk konsep diri anak. Konsep diri anak akan terus mengalami perubahan dari masa kecil sampai dewasa. Konsep diri anak akan bertambah baik dan matang tergantung pada pengalaman pribadinya selama berinteraksi dengan lingkungannya. Karena itu apabila pendidikan karakter sudah tertanam sejak kecil maka diharapkan kelak anak menjadi pribadi yang mulia, terhindar dari tindakan-tindakan dan sikap yang melanggar hukum, dan konsep diri anak akan semakin matang.

Model karakter dalam Yahya Khan Ada empat yang selama ini diketahui dan dilaksanakan dalam proses pendidikan, yaitu sebagai berikut (Khan, 2010) :

1. Pendidikan karakter berbasis nilai religius, yang merupakan kebenaran wahyu Tuhan (konversi moral).

2. Pendidikan karakter berbasis nilai budaya, antara lain yang berupa budi pekerti, pancasila, apresiasi sastra, keteladanan, tokoh -tokoh sejarah, dan para pemimpin bangsa (konservasi budaya).

3. Pendidikan karakter berbasis lingkungan (konservasi lingkungan).

4. Pendidikan karakter berbasis potensi diri, yaitu sikap pribadi, hasil proses kesadaran pemberdayaan potensi diri yang diarahkan untuk meningkatkan kualitas pendidikan (konservasi humanis).

Karakter adalah bagian dari kebiasaan yang sering lakukan, kemudian menjadi hal yang melekat dalam diri dan berakhir menjadi identitas. Anak usia dini mengutip Jhon Locke adalah kertas putih, dan sebelumnya Nabi Muhammad SAW. Menjelaskan dalam haditsnya, bahwa setiap anak terlahir 
suci (Fithrah) tergantung pendidikan orang tua dan orang sekelilingnya. Karena anak usia adalah peniru yang ulung, yang menurut psikolog Elly Risman seorang anak akan belajar, terdidik dan berkarater dengan 2 kata yaitu : pengalaman dan pembiasaan.

Dengan kata lain pendidikan karakter untuk anak usia dini sepatutnya dilakukan dan ditanamkan dengan kegiatan yang memberikan pengalaman yang menyenangkan sehingga tercipta pembiasaan dan menjadi karakter dan identitas yang melekat padanya.

\section{Bermain sentra Anak Usia Dini}

Masa kanak-kanak adalah masa bermain, oleh karena itu bermain merupakan kegiatan anak sehari-hari, dalam kehidupan anak-anak, sebagian besar waktunya dihabiskan dengan aktivitas bermain. Kegiatan bermain memberikan kesempatan pada anak untuk bereksplorasi. Sehingga dengan bermain akan terjadi proses pembelajaran.

Bermain merupakan suatu kegiatan yang positif. Seseorang yang terlibat dalam bermain akan diliputi oleh emosi-emosi positif, sehingga orang tersebut akan diliputi rasa senang ketika melakukan kegiatan bermain. Selain itu kegiatan bermain adalah kegiatan yang fleksibel dan dapat dengan mudah beralih dari aktivitas satu ke aktivitas lain.

Bermain dapat mencegah kondisi yang tidak menyenangkan yang dialami anak. Hal ini menunjukan bahwa bermain merupakan kegiatan yang diperlukan anak untuk proses berpikir karena menunjang perkembangan intelektual,dan cara berpikir anak. Oleh sebab itu, kegiatan pembelajaran yang dilakukan melalui bermain dan bermain seraya belajar akan menyenangkan untuk anak.

Aktivitas bermain penting bagi perkembangan anak. Anak perlu mengalami berbagai jenis aktivitas bermain agar dapat berkembang secara normal. Pada saat aktivitas tersebut berlangsung, perkembangan berbagai aspek pada individu mengalami perubahan ke arah yang lebih baik. Aktivitas bermain menjadi sangat beragam bersamaan dengan bertambahnya usia anak, karena intelektual anak berkembang. Begitu juga dengan sosial dan emosional anak akan bertambah luas karena anak berinteraksi dengan banyak orang baik dewasa maupun teman sebaya.

Banyak makna yang akan diperoleh Saat bermain. Menurut Froberg dalam Dockett \& Fleer bermain bagi anak merupakan kegiatan simbolik bermakna, aktif, menyenangkan, suka rela, dibatasi aturan, episodik (sepotongsepotong). Dengan bermain anak membangun pengetahuan dan kemampuan memecahkan masalah. (Docket Sue dan Fleer Marilyn, 2000)

Bermain melibatkan berbagai aktivitas baik fisik maupun mental. Karena dengan bermain anak menggunakan tubuhnya untuk bergerak, berlari, 
berjalan, melompat, memegang, melempar dan sebagainya. Bermain membuat anak-anak dapat menggunakan kemampuan psikis seperti mengamati. Berimajinasi dan berpikir, bermain adalah kegiatan yang menyenangkan untuk anak, sehingga pendidik dapat menggunakan kegiatan bermain untuk sarana belajar bagi anak. Aktifitas bermain tidak terfokus pada hasil kegiatan tetapi pada proses. Melalui bermain anak dapat memenuhi kebutuhan yang berkaitan dengan aspek-aspek perkembangannya seperti kebutuhan fisik, sosial, emosi dan intelektual. Kegiatan anak dalam bermain didasarkan pada motivasi intrinsik. Artinya anak bermain kalau dia ingin main. Mereka juga memilih untuk tidak akan terlibat dalam bermain kalau tidak mau bermain, dengan demikian bermain bukan hal yang dapat dipaksakan.

Pada saat bermain tanpa disadari anak dengan sendirinya akan mendapat pengalaman dari kegiatan yang dilakukannnya. Hal ini meliputi beberapa aspek perkembangan anak, aspek-aspek ini berkembang melalui aktivitas bermain. Hal tersebut selaras dengan pendapat Cowel dan Hazelton dalam Sukintaka yang menyatakan bahwa melalui bermain akan terjadi perubahan yang positif dalam hal jasmani, sosial, mental, dan moral. (Sukintaka, 1998). Perubahan yang positif dalam hal jasmani meliputi pertumbuhan dan perkembangan jasmani, kebugaran jasmani serta sehat jasmani. Bermain juga membawa perubahan positif pada ranah sosial melalui aktivitas bermain yaitu terjadinya kesadaran akan bekerjasama, rasa saling mempercayai, saling menghormati, saling tenggang rasa, rasa solider, saling menolong antar anggota untuk berusaha bersama mencapai suatu tujuan yang diinginkan. Melalui aktivitas bermain anak juga belajar menaati suatu peraturan, disiplin, dan tanggungjawab, sehingga anak mampu bermasyarakat secara baik.

Perubahan positif dalam mental terjadi melalui aktivitas bermain terutama dalam hal pengembangan rasa percaya diri. Tanpa sengaja aktifitas bermain melatih anak untuk terbiasa menghadapi berbagai tantangan baik dari dalam dirinya seperti rasa takut, cemas, keberanian, minat, motivasi, fisik, maupun psikis dengan mengamati situasi atau kondisi dalam arena permainan yang bervariatif, sehingga anak-anak mampu menyesuaikan diri dan ini memupuk kepada rasa percaya diri yang tinggi. Perubahan secara positif pada faktor moral yaitu bahwa melalui aktivitas bermain anak-anak dituntut untuk selalu bertindak jujur, disiplin, adil, tidak curang, tanggung jawab, menghargai teman atau lawan main, yang semuanya mengarah kepada perbuatan atau tingkah laku yang baik, sehingga dengan kebiasaan semacam itu dapat diduga anak-anak akan mengalami perubahan tingkah laku yang mengarah kepada perbuatan yang baik atau anak mengalami perubahan moral secara positif. 
Melakukan kegiatan bermain akan mendorong terjadinya value transfer atau proses pengenalan nilai-nilai positif kepada anak, salah satu nilai positif tersebut adalah karakter. Paul Tough mengungkapkan beberapa karkater yang dapat membantu pada kualitas dan mengarah pada kesuksesan belajar dan dalam kehidupan yaitu, rasa ingin tahu, pengendalian diri, kesadaran, optimisme, dan ketekunan. (Tough, 2012) Kriteria anak yang memiliki karakter yang baik adalah mempunyai sifat pantang menyerah dan sportivitas yang tinggi. Sebab, sikap tersebut penting dalam menjalani kehidupan sehariharinya. Selain itu, manfaat pembangunan karakter bagi sang anak adalah sebagai bekal bagi anak dalam menghadapi berbagai persoalan yang mereka alami sehari-hari di kemudian hari. Hal tersebut memberikan pandangan bahwa peran dan manfaat bermain juga dapat membantu pengembangan karakter anak.

Dengan demikian bermain adalah suatu aktivitas yang dilakukan anak dengan penuh kebebasan untuk bereksplorasi, spontan mapun direncana, berinteraksi maupun sendiri, dengan menggunakan benda-benda di sekitarnya, dilakukan dengan senang (gembira), menggunakan daya khayal, panca indra, dan seluruh anggota tubuhnya, membantu anak mempelajari tentang dirinya, orang lain, dan lingkungan, sehingga dapat mempengaruhi semua aspek. Bermain merupakan merupakan alat bagi anak untuk menjelajahi dunianya, dari yang tidak dikenali sampai diketahui, dan dari yang tidak dapat diperbuatnya sampai mampu melakukannya.

Model pembelajaran sentra ini pertama kali ditemukan oleh Helen Parkhust seorang pendidik, penulis dan dosen yang merintis sekolah Dalton yang berawal dari rencana Dalton. Soejono menyatakan bahwa teori ini muncul setelah melihat perkembangan pendidikan di Amerika Serikat yang dikembangkan Maria Montessori memiliki berbagai kekurangan antara lain: (Novitawati, 2013)

1. Satu anak terlalu terikat dengan cara menyelesaikan pekerjaan karena semua alat pelajaran harus dipakai dengan cara tertentu

2. Dalam sistem montessori tidak terdapat pendidikan sosial untuk kepentingan bersama yang ada hanya pendidikan secara individual

3. Mengabaikan kebaikan sistem klasikal.

Kemudian kegiatan belajar sentra ini dikenal dengan BCCT (Beyond Centers and Circle Time) yaitu model kurikulum pendidikan anak usia dini yang didisain oleh Pamela C. Phelps, Ph.D., seorang pendidik yang telah 40 tahun lebih meneliti bidang pendidikan anak usia dini. Phelps mengembangkan metode BCCT di lembaga pendidikan dan penelitian Creative Center for Childhood Research and Training (CCCRT), Tallahassee, Florida, Amerika Serikat. Di dalam institusi itu, ia mengelola Creative Pre-School, yang sejak tahun 1989 ditetapkan sebagai sebuah model pendidikan di negara bagian dan 
kemudian menjadi nasional sebagai sekolah usia dini inklusif, yang dapat melayani anak-anak berkebutuhan khusus. (Yudhistira, 2012)

Metode Sentra atau BCCT didisain dari perpaduan berbagai teori yang berkonsentrasi dalam pendidikan anak usia dini seperti Sara Smilanski dan Charles Wolfgang untuk memenuhi kebutuhan tiga jenis main sebagai model belajar anak usia dini. Ketiga jenis main yang dibutuhkan anak usia dini itu adalah main sensorimotor, main pembangunan, dan main peran. Pemenuhan kebutuhan ketiga jenis main dijalankan secara terpadu dan terukur sesuai dengan tahap-tahap perkembangan anak. Ketiga jenis main itu disediakan di Sentra-Sentra.

Sentra-Sentra adalah unit-unit tempat bermain yang berisi alat permainan edukatif (APE) yang variatif sesuai kebutuhan anak dan jenis mainnya. Dalam konsep murni yang dirancang Phelps, kebutuhan tiga jenis main dipenuhi di Sentra Bahan Alam, Sentra Persiapan, Sentra Main Peran Kecil, Sentra Main Peran Besar, Sentra Seni, dan Sentra Balok. Dengan pengelompokan alat permainan edukatif dan pengkondisian aktivitas mainnya secara spesifik, masing-masing sentra mempunyai makna dan tujuan yang berbeda-beda dalam mengembangkan aspek-aspek tumbuh-kembang anak. Namun demikian, setiap sentra pada prinsipnya mempersiapkan kesempatan anak untuk melakukan ketiga jenis main. dan bertujuan mengembangkan kemampuan setiap anak sesuai tahap perkembangannya. Pembangunan kemampuan itu meliputi enam aspek perkembangan anak yaitu psikomotor, afeksi, kognisi, sosial, bahasa, dan aestetika.

Dalam merencanakan kegiatan main, guru memperhatikan dengan teliti kesesuaian jumlah aktivitas main (densitas) dan lama proses bermain (intensitas). Pengalaman-pengalaman main dirancang dalam rangka mendukung anak melalui fase-fase perkembangannya secara sehat dan lancar. Kegiatan sentra pun tak terlepas dari tema sebagai payung dari setiap kegiatan di sentra. Pijakan (Scaffolding) pun menjadi nilai ukur dalam keberhasilan pembelajaran dengan metode sentra ini. Ada 4 pijakan yang diterapkan dalam kegiatan bermain sentra yaitu : pijakan lingkungan, pijakan sebelum main, pijakan individu dan pijakan setelah main.

\section{METODE}

Metode yang digunakan dalam penelitian ini adalah metode kualitatif dengan peneliti sebagai instrumen utama. Metode kualitatif digunakan mengingat penelitian ini bertujuan untuk menemukan sesuatu yang baru khususnya yang berkaitan dengan pembelajaran karakter anak usia dini dalam kegiatan sentra. Oleh sebab itu kebutuhan utama dalam penelitian ini adalah menemukan fakta-fakta empiris secara langsung di lapangan. 
Penggunaan metode kualitatif sesuai dengan pengertian metode kualitatif sebagaimana dikemukakan Bogdan dan Taylor, bahwa metode kualitatif merupakan suatu cara dalam penelitian yang menghasilkan data deskriptif yaitu berupaya menghasilkan tulisan atau perkataan yang diucapkan serta mengamati perilaku (C.Bogdan,Robert and Taylor Steven J., 1975). Pendapat senada dikemukakan Arifin, bahwa metode kualitatif dimaksudkan untuk menemukan masalah dan menyajikan secara langsung hakekat antara penulis dan responden, serta untuk memperoleh informasi mengenai orang dengan cara mengamati dan mewawancarai mereka. Spradley mengidentifikasi tiga elemen penting yang harus ada dalam latar penelitian, yaitu: tempat, pelaku dan aktifitas yang dilakukan. Dengan demikian penelitian kualitatif sesuai untuk meneliti dan mendeskripsikan data dengan tulisan berdasarkan data diambil melalui pengamatan perilaku secara langsung dan wawancara dalam lingkungannya (Spradley, 1980). Penelitian kualitatif memiliki ciri-ciri tertentu. Ciri tersebut diungkapkan oleh Guba and Lincoln keduanya menyatakan bahwa, salah satu ciri atau perbedaan utama penelitian naturalistik adalah paradigma dunia yang ada padanya hal itu didasarkan. (Yvonna S. \& Egon G. Guba Lincoln, 1985) Dengan kata lain hal yang dilihat dan didengar di lapangan maka hal tersebut merupakan hasil yang dapat dijadikan data konkrit dalam penelitian ini. Ada beberapa butir kunci mengenai paradigma naturalistik, yakni:

1. Realitas adalah jamak, dibentuk dan holistik.

2. Hubungan antara peneliti dengan yang diteliti adalah interaktif, tidak dapat dipisah.

3. Tidak ada generalisasi data dalam penelitian ini, hanya waktu dan konteks yang dimungkinkan hipotesa kerja

4. Seluruh keutuhan adalah dalam keadaan saling mempertajam secera simultan, sehingga tidak mungkin untuk membedakan sebab dari akibat.

5. penelitian ini adalah terikat nilai.

Hal di atas menjelaskan bahwa, dalam penelitian naturalistik masalah yang muncul itu harus dilihat secara keseluruhan antara yang benar terjadi dan sebab, kemudian dalam penelitian ini, antara peneliti dan yang diteliti memiliki interaksi dan bukan data yang dibuat-buat / tidak ada generalisasi data, semua data yang didapat adalah sesuai yang ada di lapangan, sebab dan akibat memiliki keterikatan satu sama lainnya, sedangkan seluruh keutuhan adalah dalam keadaan saling mempertajam sehingga tidak mungkin untuk membedakan sebab dari akibat,. Terakhir dari ciri ini adalah peranan nilai bahwa penelitian ini merupakan keinginan peneliti sendiri sebagai upaya mencari tahu sebab akibat mengenai fakta di lapangan/pada sesuatu hal yang sedang terjadi. 


\section{HASIL DAN PEMBAHASAN}

Hasil temuan tentang pendidikan karakter dalam kegiatan sentra dan menginterpretasikannya dengan pendapat para ahli yang dapat dijadikan acuan dalam memperkuat temuan penelitian. Pembahasan ini dilakukan agar dapat memaparkan hasil temuan sehingga menjadi teori subtantif. Hasil temuan tentang pendidikan karakter anak usia dini dalam pembelajaran sentra dibahas dalam dua pokok bahasan yaitu pelaksanaan pembelajaran dan efektivitas pendidikan karakter dalam pembelajaran sentra yang dilaksankan di TK Islamic Village.

\section{Pendidikan Karakter saat Pengkondisian awal}

Internalisasi karakter pada saat pengkondisin awal dilakukan sejak kedatangan anak-anak ke sekolah. Guru menunggu di pintu gerbang sekolah untuk menyambut kedatangan siswa, anak-anak memberi salam dan mencium tangan semua guru yang berdiri hal ini menunjukkan karakter hormat dan santun, kemudian anak-anak diarahkan ke kelas masing-masing untuk menyimpan tasnya. Guru mengajak anak-anak berkumpul di halaman sekolah untuk berbaris sesuai dengan kelasnya masing-masing ini melatih karakter disiplin pada anak. Setelah anak-anak berbaris, guru menanyakan siapa yang akan memimpin barisan, hal ini dilakukan untuk melatih kepemimpinan dan percaya diri. Sebelum doa dimulai guru mengajak anak bernyanyi dan bertepuk (ice breaking) kegiatan ini dilakukan untuk memberi pendinginan kepada anak, supaya mereka senang ketika memasuki kelasnya, Kegiatan berdoa yang dilakukan dalam mengawali kegiatan menstimulasi anak memiliki karakter religius. Setelah selesai berdoa anak-anak pergi ke sentra masing-masing dengan didampingi guru. Sebelum kegiatan dimulai guru meminta anak ke kamar mandi untuk kegiatan toilet training dan berwudhu.

\section{Pendidikan Karakter saat Pembelajaran Sentra}

\section{Pijakan Lingkungan Main}

Pada pijakan ini guru menempatkan alat dan bahan bermain yang akan digunakan dan menggambarkan rencana pembelajaran yang telah dibuat, sehingga tujuan anak selama bermain dengan media tersebut dapat tercapai.

Hal ini senada dengan pendapat konstruktivisme yang beranggapan bahwa pengetahuan adalah hasil konstruksi manusia melalui interaksi dengan objek, fenomena dan lingkungan. Menurut Helen Parkhust (1807) seorang ahli pedagogi di Amerika, menjelaskan bahwa kegiatan pengajaran harus memberikan peluang kepada murid untuk berinteraksi, bersosialisasi dan bekeja sama dengan murid lain dalam menyelesaikan tugas tertentu secara mandiri (Eliza D. , 2013) 
Selain itu, pijakan ini diharapkan anak bisa membaca lingkungan yang didisplay oleh gurunya sehingga membentuk karakter rasa ingin tahu, dan menjadi anak yang understading dan adaptable (Piaget).

\section{Pijakan Sebelum Main}

Guru dan anak membuat posisi lingkaran lalu guru memberi salam kepada anak dan dilanjutkan dengan kegiatan :

a. Menanyakan kegiatan anak-anak sebelum berangkat ke sekolah, tidak lupa guru meminta anak untuk memperhatikan siapa saja temanya yang tidak hadir pada hari itu (karakter peduli sosial, empati).

b. Membiasakan anak untuk melakukan sholat dhuha setiap hari sebelum melakukan aktivitas lain. Selesai sholat anak-anak merapihkan peralatan sholat ke dalam lokernya masing-masing (karakter religius, dan disiplin).

c. Berdo'a bersama, anak secara bergilir untuk memimpin do'a setiap hari dilanjutkan makan bersama (snack time). Selesai makan mereka merapihkan alat makannya masing-masing dan membersihkan makanan dan minuman yang tumpah/remeh-remeh (karakter pemimpin, mandiri, tanggung jawab, dan peduli lingkungan).

d. Guru senantiasa memberi pujian kepada anak-anak yang melakukan kebaikan (karakter hormat dan menghargai)

e. Guru mengingatkan kepada anak-anak untuk mencuci tangan setelah makan dan selesai beraktivitas (mengajarkan karakter kebersihan dan peduli lingkungan).

Menurut Langeveld, "Pendidikan ialah setiap usaha, pengaruh, perlindungan dan bantuan yang diberikan kepada anak tertuju kepada pendewasaan anak itu, atau lebih tepat membantu anak agar cukup cakap melaksanakan tugas hidupnya sendiri. Pengaruh itu datangnya dari orang dewasa (atau yang diciptakan oleh orang dewasa seperti sekolah, buku, putaran hidup sehari-hari, dsb)."

Hasil temuan diatas merupakan interpretasi pandangan-pandangan para ahli dalam memberi pengertian terhadap pendidikan dan belajar. Dapat dijelaskan bahwa kegiatan yang dilakukan di TK Islamic Village dalam menanamkan pendidikan karakter pada anak usia dini memang dilakukan melalui stimulus dan pembiasaan yang dipraktekkan setiap hari, hal ini juga menunjukkan bahwa anak belajar dengan melihat dan mendengar langsung dari guru dan orang-orang dewasa di sekitar anak berada.

Bertitik tolak dari analisis hasil penelitian maka dirumuskan teori subtantif sebagai berikut: "Apabila guru telah melakukan serangkaian proses pembelajaran ketika pengkondisian awal seperti menyambut anak ketika datang ke sekolah, mengajarkan anak untuk memberi salam dan mencium tangan guru sebagai bentuk hormat, meyimpan barang-barang di lokernya 
masing-masing, mengajak anak-anak berbaris, berdo'a bersama sebelum memulai pelajaran, melaksanakan toilet training, berwudhu dan sholat dhuha, makan bersama. Maka langkah-langkah yang dilakukan guru merupakan upaya dalam pendidikan karakter melalui pembiasaan dalam pembelajaran sentra.

\section{Pijakan Selama Main}

Anak melakukan kegiatan bermain yang sudah disiapkan guru. Pada pijakan ini guru memberikan pengalaman bermain bermakna kepada anak untuk bisa diterapkan dalam kehidupan anak-anak secara nyata nantinya. Seperti pada kegiatan :

a. Di sentra bermain peran, anak-anak berlatih untuk menjadi individu yang bisa diterima lingkungannya, anggota masyarakat yang taat pada aturan main. Anak-anak diberi kesempatan untuk memilih peran. Disini anak diajarkan untuk berani mengambil keputusan (ciri dari karakter kemandirian dan bekerja sama).

b. Kegiatan membuat manik-manik dan menyelesaikan tugas yang diberikan guru, di sentra ICT dan ini mengajarkan anak untuk bekerja keras dan tanggung jawab.

c. Kegiatan membuat konstruksi dengan balok-balok mengajarkan anak-anak mengklasifikasi, mengidentifikasi, menganalisis dan memecahkan masalah dalam menyusun sebuah bangunan yang kuat berdasarkan tema yang sedang dibahas (karakter bekerja keras, kesabaran, berpikir kreatif, analitik dan inovatif).

d. Di sentra persiapan anak-anak diberikan pengalaman untuk membaca dan menulis dalam rangka mempersiapkan anak masuk ke jenjang selanjutnya.

Menurut John Dewey, “ Pendidikan adalah upaya pembentukan kecakapan-kecakapan fundamental secara intelektual dan emosional terhadap alam semesta dan sesama manusia. Para ilmuan dalam Steve Biddulph menjelaskan bahwa sebuah pesan akan lebih dalam tertanam ke dalam benak seseorang bila penyampaian pesan itu dibarengi dengan sinyal atau tindakan yang menguatkan pesan tersebut, misalnya dengan sentuhan, kontak mata, atau suara yang keras dan tinggi. (Biddulph, 2004) Menurut Goldberg perkembangan kognitif di mulai dari aktivitas-aktivitas tangan dan pengalaman langsung. Menurut Froberg dalam Dockett \& Fleer, bermain bagi anak merupakan kegiatan simbolik bermakna, aktif, menyenangkan, suka rela, dibatasi aturan, episodik (sepotong-sepotong). proses pada anak membangun pengetahuan dan ketrampilan memecahkan masalah.

Bobby De Porter mengungkapkan tentang Gaya belajar yaitu cara belajar yang terdiri dari berbagai kombinasi untuk menyerap, lalu mengatur, dan 
mengolah informasi, yang terdiri dari: ( Deporter, Mike, Bobby \& Hernacki, , 2000)

a. Visual merupakan cara belajar dengan cara melihat atau menggunakan matanya.

b. Auditorial : belajar dengan cara mendengar

c. Kinestetik : belajar dengan cara bergerak,bekerja, dan menyentuh.

Temuan pada pijakan main menunjukkan bahwa pendidikan karakter dalam pembelajaran sentra di TK Islamic Village telah berjalan dengan baik, guru memberikan kebebasan kepada anak dalam meilih kegiatan yang disukai yang merupakan salah satu ciri dari pembelajaran sentra, guru juga memberikan kesempatan pada anak-anak untuk bereksplorasi dan berekspresi dalam setiap kegiatan yang diberikan, hal ini terlihat pada saat kegiatan di sentra bermain peran dan sentra balok. meskipun belum sepenuhnya menerapkan model sentra ini secara utuh. Namun demikian TK Islamic Village telah menerapkan prinsip belajar pada anak usia dini sesuai dengan kajian teori pendidikan dan perkembangan anak usia dini. Pembelajaran dilakukan melalui proses diskusi kepala sekolah dan guru, kajian analitik kurikulum, dan observasi guru juga kepala sekolah ke TK Al Falah sebagai basis/model dari pembelajaran sentra.

\section{Pijakan Setelah Main}

Ketika waktu bermain selesai guru memberitahukan saatnya membereskan alat-alat main yang digunakan dengan melibatkan seluruh anak). Setelah selesai anak-anak duduk kembali dalam lingkaran, guru melakukan recalling sebagai evaluasi/review. Menanyakan kepada anakanak tentang kegiatan hari itu dan perasaan anak-anak setelah melakukan aktivitas. Anak-anak dengan antusias menjawab setiap pertanyaan yang diajukan dengan jawaban masing-masing sesuai dengan apa yang anak dapatkan pada hari itu. Hal ini melatih daya ingat, kecakapan anak-anak dalam merespon serta mengemukakan pandangan dan persaannya (mengajarkan karakter percaya diri, dan kemandirian).

Menurut Katz seorang peneliti perkembangan otak di Amerika mengungkapkan bahwa otak bertugas menerima, mengatur dan juga mendistribusikan informasi untuk menjadi pedoman tindakan seseorang dan juga bertugas menyimpan informasi penting untuk digunakan di masa depan. (Katz, 2007). Para penganut teori kognitif menurut Good dan Brophy dalam Ella Yulaelawati memandang belajar sebagai pelibatan penguasaan atau penataan kembali struktur kognitif seseorang untuk memproses dan menyimpan informasi. Latihan-latihan yang diberikan secara baik dan tepat akan sangat berguna untuk mengembangkan otak yang akan diwujudkan dalam prilaku nyata seseorang. (Yulaelawati, 2004) 
Bertitik tolak dari analisis hasil penelitian maka dirumuskan teori subtantif sebagai berikut: "Apabila guru telah melakukan serangkaian proses pembelajaran seperti guru terlebih dahulu melakukan pijakan lingkungan main, pijakan sebelum main, pijakan main dan pijakan setelah main. Memberi kebebasan kepada anak-anak untuk menentukan sendiri kegiatan yang akan dilakukan, memberi kebebasan bereksplorasi dan berekspresi, mendegarkan pendapat/gagasan anak-anak ketika sedang bermain, membuat rancangan kegiatan dan evaluasi, pembelajaran melibatkan mata, telinga dan sentuhan dalam artian anak melihat, mendengar, menyentuh/mencoba. Maka langkah-langkah yang dilakukan guru dalam pendidikan karakter melalui pembelajaran sentra sudah berjalan efektif.

\section{SIMPULAN}

Pendidikan karakter anak dalam pembelajaran sentra yang dilaksanakan di TK Islamic Village dilakukan sejak kedatangan anak ke sekolah dan dilakukan di semua sentra. Pendidikan karakter dilakukan melalui 4 pijakan dalam pembelajaran sentra, yaitu pijakan lingkungan main, pijakan sebelum main, pijakan main, dan pijakan setelah main. Sebelum memulai materi guru selalu menjelaskan aturan main dalam setiap sentra masing-masing. Pendidikan karakter dalam pembelajaran sentra berjalan efektif. Hal ini bisa dilihat dari aktivitas atau perilaku yang muncul dari anak pada setiap pembelajaran berlangsung.

\section{IMPLIKASI}

Pendidikan karakter dalam pembelajaran sentra yang dilaksanakan memberikan implikasi dalam mengembangkan keterampilan/kecakapan pada anak dalam menghadapi masa depannya kelak. Di samping itu guru juga dapat lebih meningkatkan kemampuan dan motivasinya dalam mempelajari hal-hal baru terkait dengan pengembangan karakter sebagai upaya mepersiapkan generasi alpha.

\section{DAFTAR PUSTAKA}

Auerbacch, Stevanne (2007). Smart Play Smart Toys. Jakarta: PT Buana Ilmu Populer

Sukmadinata, Nana Syaodih. (2011). Metode Penelitian Pendidikan. Bandung : PT Remaja Rosdakarya

Bogdan, Robert C and Steven J. Taylor. (1975). Introduction to Qualitative Research Method. New York: John Willey and Son

Crain, William, Penerj. Yudi Santoso (2007). Teori Perkembangan Konsep dan Aplikasi, Yogyakarta: Penerbit Pustaka Pelajar 
Deporter, Bobby \& Mike Hernacki (2000). Quantum Learning, Cet.VII. Bandung: Mizan Media Utama

Delfi Eliza (2013). Penerapan Model Pembelajran Kontekstual Learning (CTL) Berbasis Centra Di Taman Kanak-Kanak. PEDAGOGI. Jurnal Ilmiah Ilmu Pendidikan, Edisi XIII: 2 Padang: Universitas Negeri Padang

Ella Yulaelawati (2004). Kurikulum dan Pembelajaran. Bandung: Pakar Raya https://www.silabus.web.id/anak-usia-dini/ diunduh 25 Oktober 2019 https://kelembagaan.ristekdikti.go.id/wp-

content/uploads/2016/08/UU no 20 th 2003.pdf diunduh 25 Oktober 2019

Khan, Yahya (2010). Pendidikan Karakter Berbasis Potensi Diri, Cet 1. Yogyakarta: Pelangi Publishing

Katz (2007). The Timing and Quality Of Early Experiences Combine To Shape Brain Architecture, Cambridge: National Scientific Council Of Developing Child, Harvard University

Lincoln, Yvonna S. \&Egon G. Guba (1985). Naturalistic Inqury. Bevery Hills: Sage Publication

Lawrence C. Katz. (2004). Mengasah Otak dalam, Praktek Sehari-hari. Batam: Interaksa

Masardi, Yudistira dan Sisca Y. (2012). Pendidikan Karakter Dengan Metode Sentra. Bekasi: Media Pustaka Sentra

Novitawati (2013). Kesiapan Sekolah Anak Taman Kanak-kanak Berbasis Model Pembelajaran Sentra. Jurnal Pendidikan Anak Usia Dini, Volume 6 (2). Jakarta

Santoso, Soegeng (2000). Pendidikan Anak Usia Dini Di Masa Mendatang, (Pidato pengukuhan guru besar Fakultas Ilmu Pendidikan)

Undang-undang Pendidikan, DepDiknas: Jakarta 2004

Sukintaka (1998). Teori Bermain Untuk Pendidikan Jasmani. Yogyakarta: FPOK IKIP

Syahrbini, Amrullah (2014). Model Pendidikan Karakter Dalam Keluarga. Jakarta: Elex Media Komputindo

Sue Dockett dan Marilyn Fleer (2000). Play and Peadagogy in Early Childhood. Australia: Harcourt Limitid

Spradley, J. P. (1980). Participant Observation. New York: Holt, Rinehart \& Winston

Tough, Paul (2012). How Children Succeed: Grit, Curiosity, and the Hidden Power of Character 